\title{
PRELIMINARY SPECTROSCOPIC STUDY OF FE-BEARING CLAY MINERALS IN ALTERED PILLOW LAVAS FROM LAMIA AREA, GREECE ${ }^{1}$
}

\author{
Katranidou B. ${ }^{1}$, Godelitsas A. ${ }^{1}$ and Sanakis I. $^{2}$ \\ ${ }^{1}$ National and Kapodistrian University of Athens, Faculty of Geology and Geoenvironment, 15784, \\ Zografou campus, Athens, Greece,vera.katranidou@gmail.com, agodel@geol.uoa.gr \\ ${ }^{2}$ NCSR "Demokritos", Institute of Materials Science, 15310, Agia Paraskevi, Attiki, Greece, \\ sanakis@ims.demokritos.gr
}

\begin{abstract}
Geological material, of greenish color, filling interspaces in altered Triassic pillow lavas of Lamia area (central Greece) was studied, for the first time in the literature. According to XRD and SEM-EDS data it predominantly consists of calcite, zeolites and clay minerals. The zeolites concern thomsonite and analcime. The clay minerals, on the basis of XRD, FTIR and Mössbauer spectroscopic measurements, constitute a $\mathrm{Fe}$-bearing phase of the illlite-glauconite-celadonite group (most likely Fe-illite). Keywords: Altered pillow lavas, clay minerals, iron, Mössbauer spectroscopy.
\end{abstract}

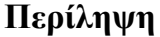

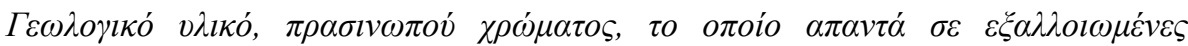

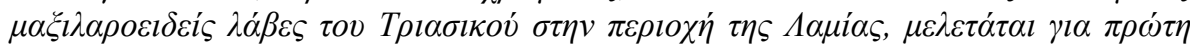

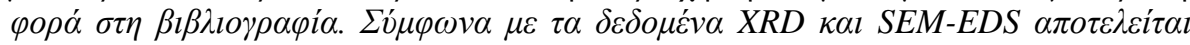

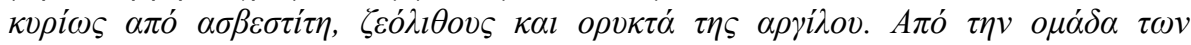

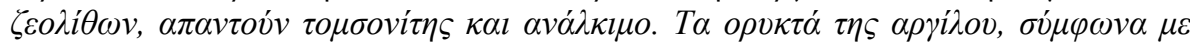

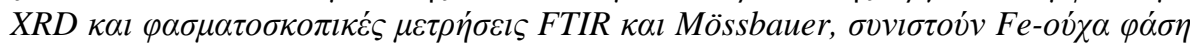

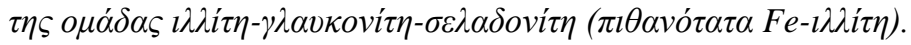

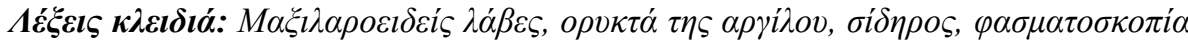
Mössbauer.

\section{Introduction}

Iron-bearing clay minerals mainly concern Fe-illlite, glauconite and celadonite (e.g. Buckley et al., 1978; Bailey et al., 1980; Odin et al., 1988; Martin et al., 1991; Meunier, 2005; Zhukhlistov, 2005; Drits et al., 2010). According to the international clay nomenclature (AIPEA committee), celadonite and glauconite are dioctahedral micas with the following general composition:

$$
\begin{aligned}
& {\left[\mathrm{Si}_{4-x} \mathrm{Al}_{x}\right] \mathrm{O}_{10}\left(\mathrm{Mg}_{1+y} \mathrm{Fe}_{1-y}^{3+}\right)(\mathrm{OH})_{2} \mathrm{~K} \quad \text { with } x(=y)<0.2} \\
& {\left[\mathrm{Si}_{4-x} \mathrm{Al}_{x}\right] \mathrm{O}_{10}\left(\mathrm{R}_{2-y}^{3+} \mathrm{R}_{2+y}\right)(\mathrm{OH})_{2} \mathrm{~K}_{x+y} \quad \text { with } x>0.3 \text { and } \mathrm{Fe}^{3+} \gg \mathrm{Al}}
\end{aligned}
$$

\footnotetext{
${ }^{1}$ Part of the the BSc Thesis of B.K.
} 
Glauconite is a low-temperature mica that grows at the sediment-seawater interface (the term glaucony indicate the green pellets either rounded or retaining the form of bioclasts: sponge spicules, foraminifer shells etc). Celadonite-group minerals are extensively occurring in deep-sea floor basalts, such as those sampled in the present study. Fe-bearing (ferric) illites, glauconite micas, and hyperaluminous glauconites do not grow in the marine environment like glaucony but in a continental environment in salt lakes or lagoons, as well as in arid soils. The layer charge of Fe-illites varies from 1 to 0.7 per $\mathrm{Si}_{4} \mathrm{O}_{10}$. The charge originates both in the tetrahedral sheet by substitutions of $\mathrm{Al}$ for $\mathrm{Si}$ and in the octahedral sheet by substitution of bivalent elements $\mathrm{R}^{2+}\left(\mathrm{Mg}, \mathrm{Fe}^{2+}\right)$ for trivalent elements $\mathrm{R}^{3+}\left(\mathrm{Al}, \mathrm{Fe}^{3+}\right)$. The iron content $\left(\mathrm{Fe}^{3+}+\mathrm{Fe}^{2+}\right)$ varies between 0.5 and 1 ion per half unit cell. The presence of a continuous solid solution domain between Fe-illites and glauconites seems unlikely for crystallographic reasons. In fact, the exact chemical composition of illites is somewhat difficult to define, despite the plenty of data in the literature. Subsequently, under the term "illite" are hidden various phases, according to whether they are defined by X-ray diffraction criteria only (absence of expandable sheets) or by a combination of criteria (XRD, morphology, composition). The general formula unit of an illite is the following:

$$
\left[\mathrm{Si}_{4-x} \mathrm{Al}_{x}\right] \mathrm{O}_{10}\left(\mathrm{R}_{2-y}^{3+} \mathrm{R}_{y}^{2+}\right)(\mathrm{OH})_{2} \mathrm{~K}_{x+y} \quad \text { with } 0.75 \leq x+y \leq 0.95
$$

This formula can be distinguished from that of glauconites whose charge is predominantly octahedral. There is apparently no continuous solid solution, as mentioned above, between illite and glauconite. In general, illites form in different natural environments: weathering environments, geothermal fields, and diagenetic environment. The scope of the present paper was a first attempt to characterize, mainly by means of Mössbauer spectroscopy, Fe-clays occurring as interpillow greenish material, together with zeolites, in Triassic pillow lavas in the area north of Lamia city, central Greece (e.g. Pe-Piper and Piper, 2002; Barth, et al., 2003; Barth and Gluhak, 2008; Tsikouras et al., 2008; Koutsovitis et al., 2012). These parent rocks are actually basalts (Figure 1).

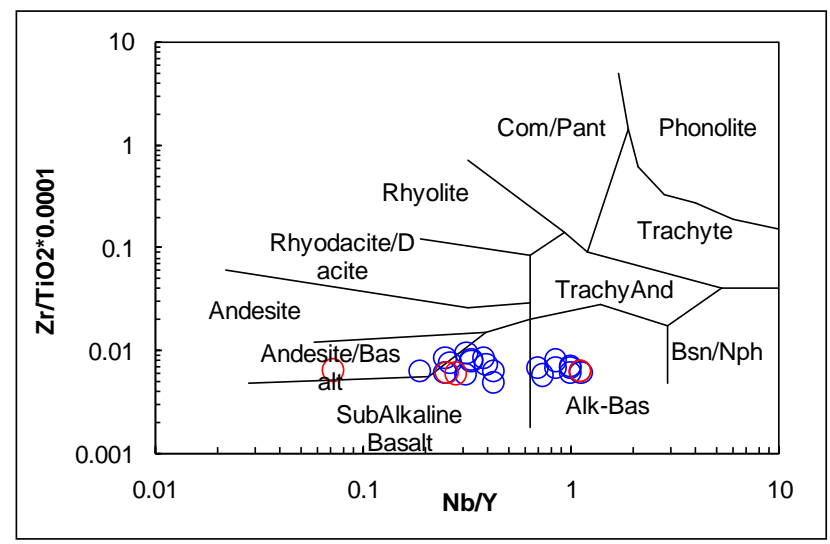

Figure 1 - Discrimination of the parent rocks using analytical data by Tsikouras et al. (2008) and Barth and Gluhak (2009).

\section{Materials and Methods}

The geological material, examined in the present study, was sampled in Triassic pillow lavas occurring in the area north of Lamia (Figure 2). A portion of the material was embedded in epoxy resin and polished, in order to be examined by Scanning Electron Microscope with Energy Dispersive Spectrometer (SEM-EDS). Moreover, the "white" part of the material as well as the greenish part, were carefully separated using an optical stereomicroscope and further pulverized for powder-XRD (PXRD), Fourier-Transform Infrared Spectroscopy (FT-IR) and Mössbauer spectroscopy investigation. 

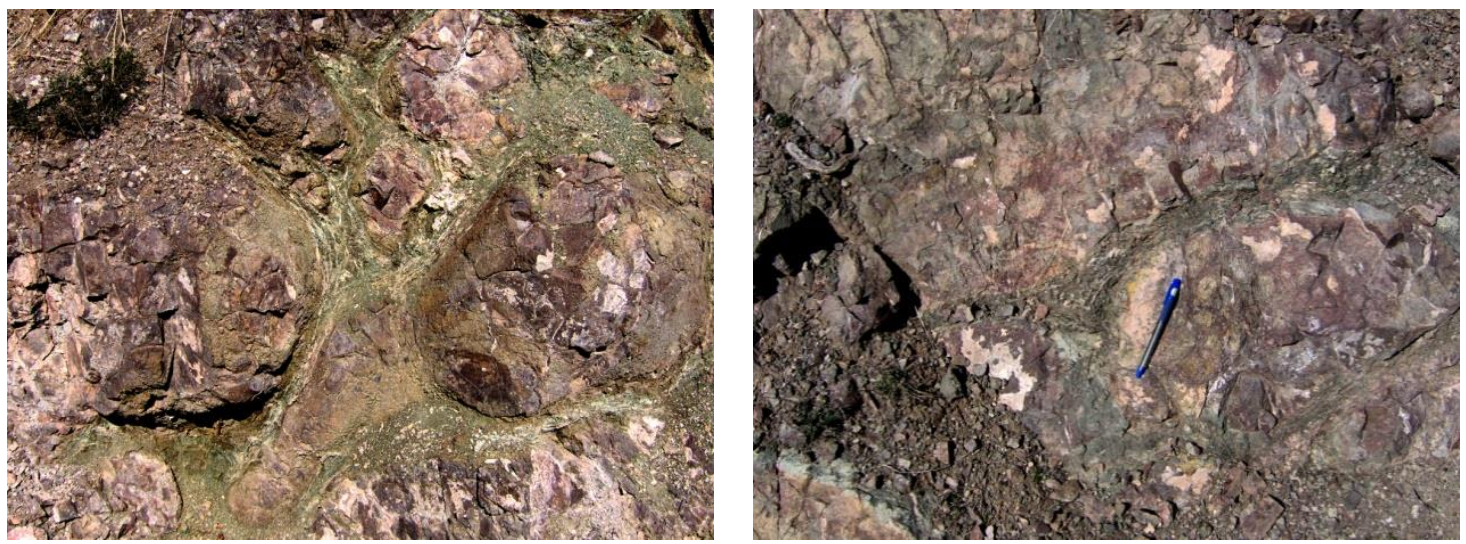

Figure 2 - Altered pillow lavas and the greenish interpillow clayey material.

The PXRD patterns were recorded by means of a Siemens D5005 (Bruker AXS) using CuK $K_{\alpha}$ radiation. The SEM-EDS investigation was carried out using a Jeol JSM-5600 microscope equipped with an Oxford EDS. The FT-IR spectroscopic measurements were performed using a Perkin Elmer Spectrum One spectrometer in the frequency range $4000-450 \mathrm{~cm}^{-1}$, at $2 \mathrm{~cm}^{-1}$ resolution, using $\mathrm{KBr}$ pellets. The Mössbauer spectra, of the previously characterized Fe-clays, were obtained using a Bruker ER-200D spectrometer at the Institute of Materials Science of NCSR "Demokritos" (Athens, Greece).

\section{Results and Discussion}

The PXRD of the initial interpillow material, containing both "white" and greenish phases, showed the presence of calcite, zeolites (analcime) and clays of the the celadonite group (Figure 3). A further investigation of the "white" part of the material revealed the presence of more zeolite group minerals, namely thomsonite (Figure 4). The presence of zeolites in altered basalts is rather common in the literature (e.g. Keith and Staples, 1985). More detailed study of the separated greenish clayey part of the material proved the existence of illite-glauconite-celadonite group clay minerals (Figure 5). The chemical composition, and particularly the increased $\mathrm{Fe}$-content of the clays, prior to spectroscopic study, was confirmed by the SEM-EDS investigation (Figure 6). It should be mentioned that it was rather unfeasible to determine the exact phase by conventional SEM-EDS, due to the nature of the clayey material limiting the application of precise microanalyses. That was attempted, after the FT-IR characterization, by cautious Mössbauer spectroscopic measurements.

The FT-IR spectra of the greenish clayey material (Figure 7) showed a peak at $3578 \mathrm{~cm}^{-1}$, featuring the hydrous components ( $\mathrm{O}-\mathrm{H}$ bonds) of Fe-clays and possibly of celadonite. Another characteristic peak at $1000 \mathrm{~cm}^{-1}$ is common in many silicate minerals, including Fe-clays, whereas the lack of a peak at $800 \mathrm{~cm}^{-1}$ is probably an indication of celadonite (e.g. Slonimskaya et al., 1986 and references therein). Nevertheless, it was not clearly stated, as in the case of SEM-EDS investigation, the exact phase in concern. 


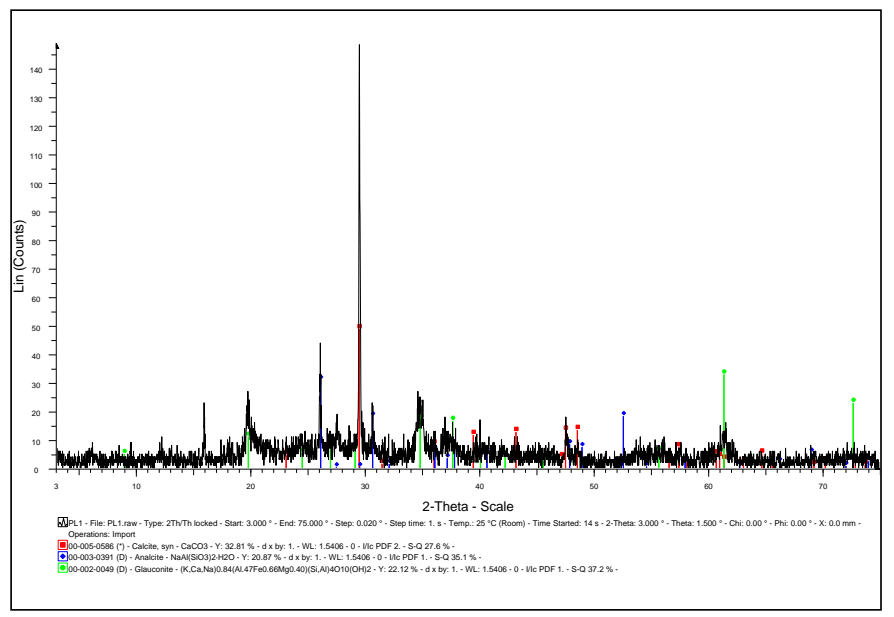

Figure 3 - PXRD pattern of the interpillow material.

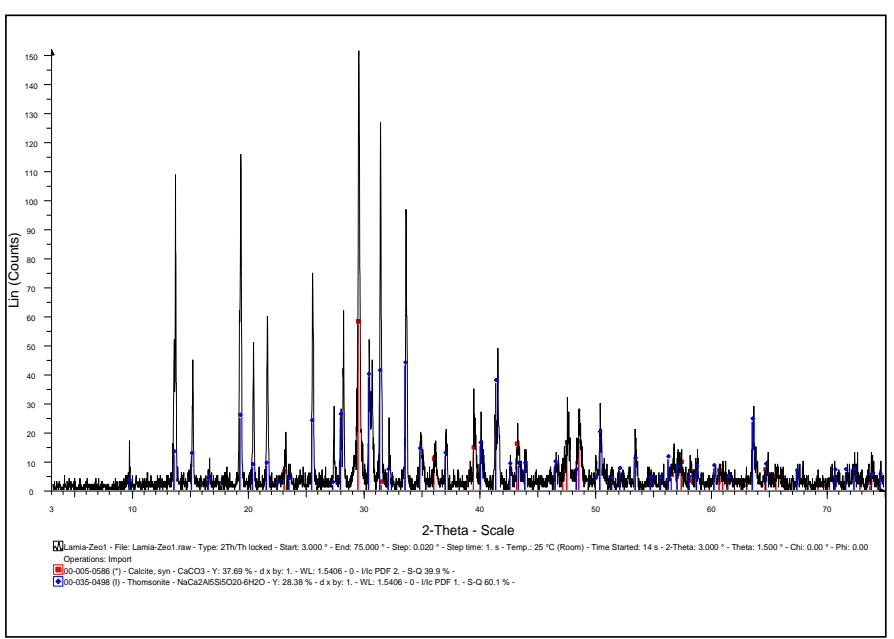

Figure 4 - PXRD of the "white" part of the material.

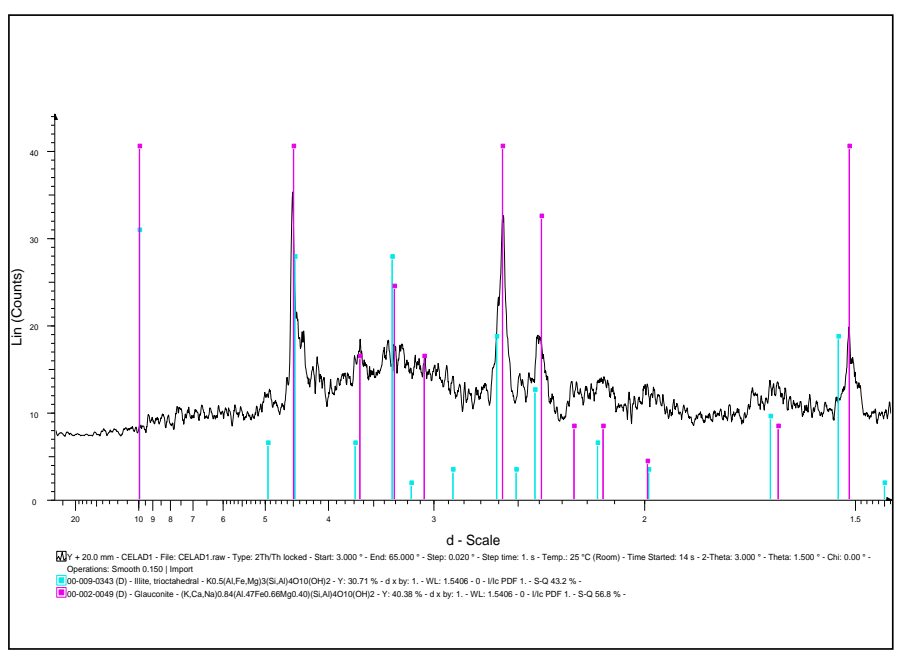

Figure 5 - PXRD of the separated greenish clayey part of the material. 

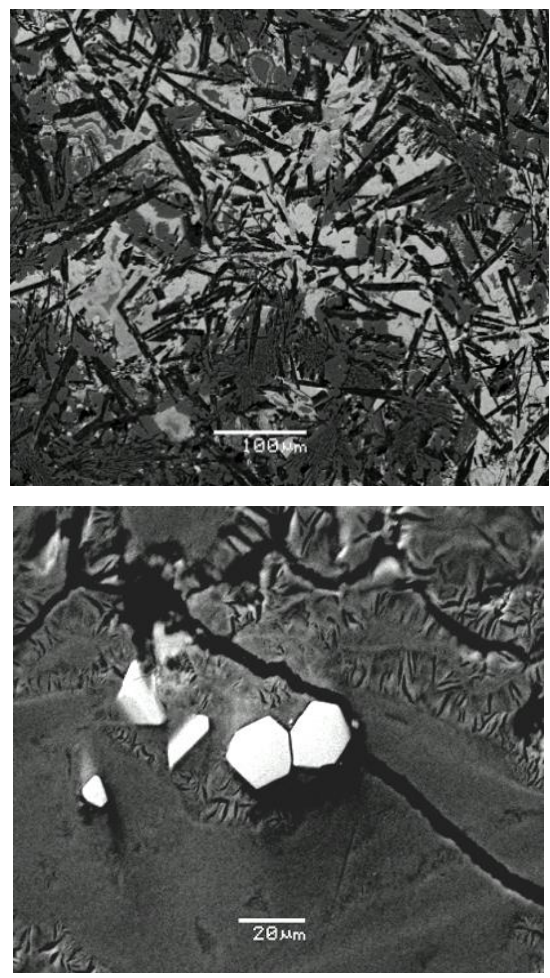
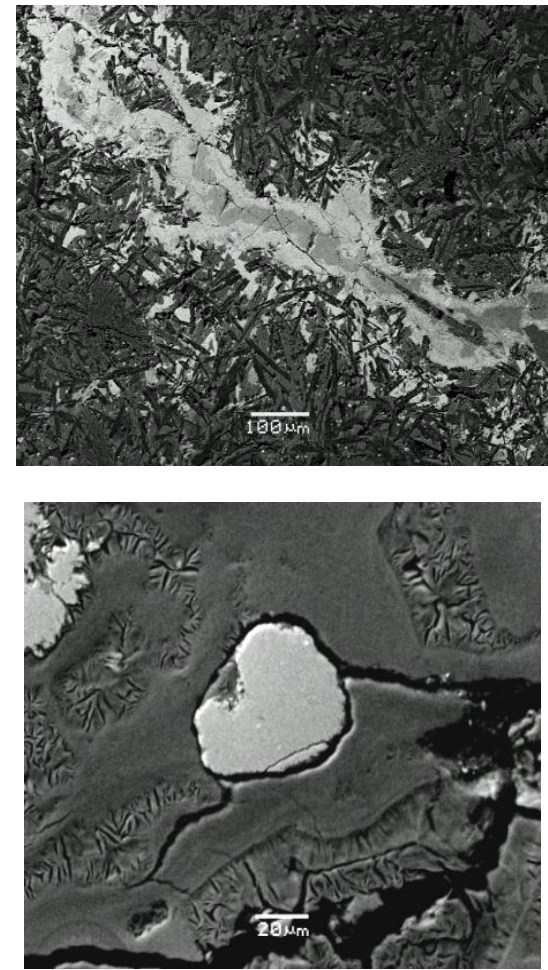

Figure 6 - SEM-EDS data concerning the studied material. Upper left: fresh parent rock; upper right: altered micro-zone containing Fe-oxides/oxyhydroxides; lower left \& right: $\mathrm{Cr}$ spinel crystals included into the Fe-clay phase.

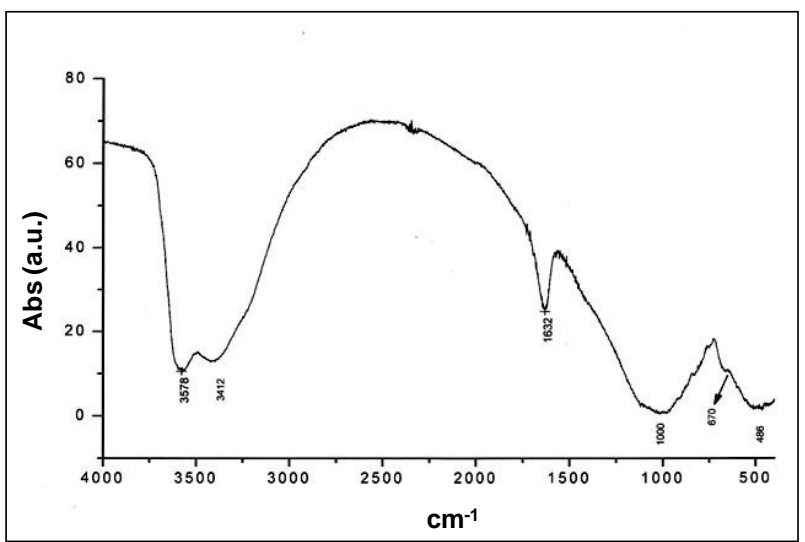

Figure 7 - Representative FT-IR spectrum of the greenish clayey material.

In the subsequent Mössbauer study, it was indicated, for first time in the literature, that the Fe-clays from Lamia altered pillow lavas contain $92 \% \mathrm{Fe}^{3+}$ and $8 \% \mathrm{Fe}^{2+}$ and may be $\mathrm{Fe}$-illites than celadonites (Figure 8; Table 1; Figure 9; e.g. Dainyak and Drits, 1987 and references therein; Drits et al., 1997 and references therein; Dyar et al., 2006 and references therein). In particular, the Mössbauer spectra show two quadrupole splitting peaks, where $\delta=0.36 \mathrm{~mm} / \mathrm{s}$ and $\Delta \mathrm{E}_{\mathrm{Q}}=0.58$ correspond to $\mathrm{Fe}^{3+}$ and $\delta=1.15$ and $\Delta \mathrm{E}_{\mathrm{Q}}=2.57$ correspond to $\mathrm{Fe}^{2+}$. It should be mentioned, that the above preliminary data, regarding nature of the Lamia Fe-clays, are going to be supported by further research, including Xray Absorption Spectroscopy measurements in the $\mathrm{Fe} K$-edge and Transmission Electron Microscopy (TEM). 


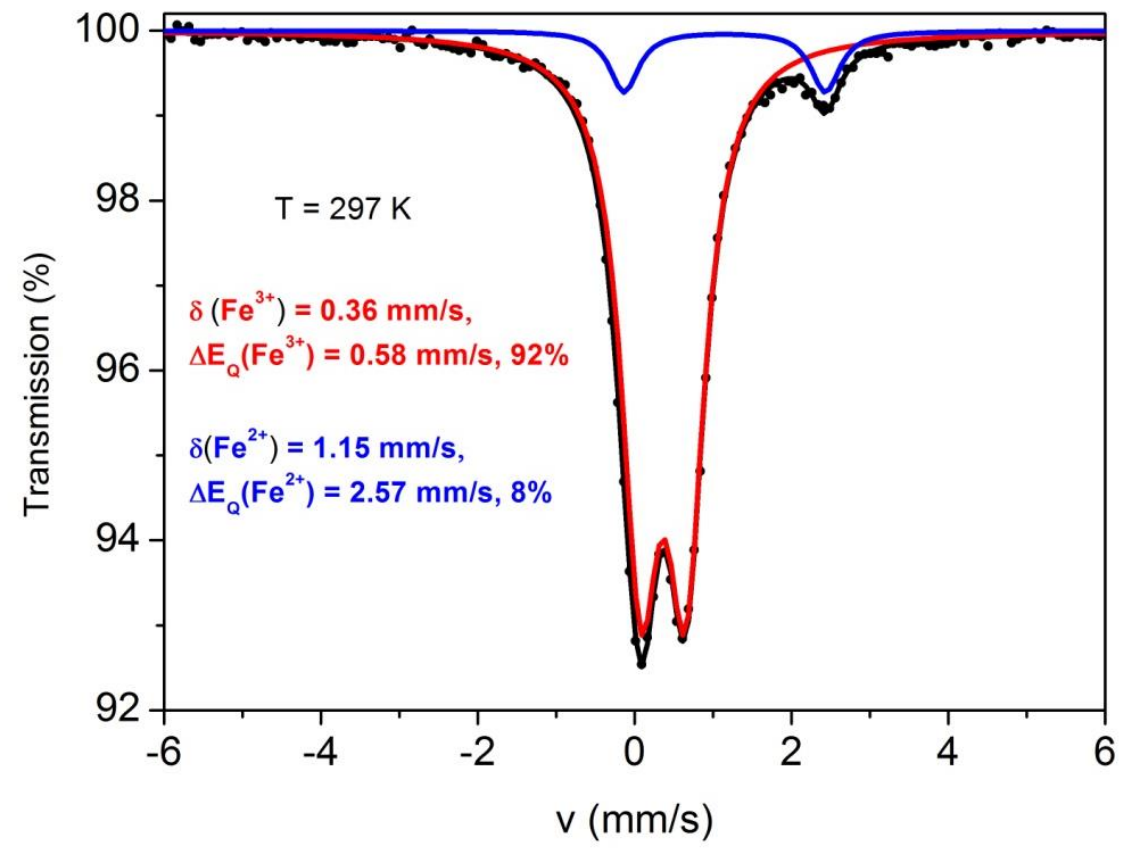

Figure 8 - Mössbauer spectrum of the greenish clayey material.

Table $1-\mathrm{Fe}^{3+}$ and $\mathrm{Fe}^{2+}$ content and $\mathrm{Fe}^{3+} / \mathrm{Fe}^{2+}$ ratios in $\mathrm{Fe}$-illlite-glauconite-celadonite group clay minerals (Bailey et al., 1980; Odin et al., 1988; Martin et al., 1991; Meunier, 2005; Zhukhlistov, 2005; Drits et al., 2010; Dainyak and Drits, 1987 and references therein; Drits et al., 1997 and references therein; Dyar et al. 2006 and references therein). 1: Celadonite; 2:

Celadonite; 3: Glauconite; 4: Glauconite; 5: Celadonite; 6: Fe-illite; 7: Glauconite; 8: Glauconite; 9: Fe-illite; 10: Fe-clay from the present study.

\begin{tabular}{|c|c|c|c|c|c|}
\hline Number & $\mathrm{Fe}^{3+}$ & $\mathrm{Fe}^{2+}$ & $\mathrm{Fe}^{3+} \%$ & $\mathrm{Fe}^{2+} \%$ & $\mathrm{Fe}^{3+} / \mathrm{Fe}^{2+}$ \\
\hline 1 & 0.96 & 0.26 & 78.69 & 21.31 & 3.69 \\
\hline 2 & 1.15 & 0.36 & 76.16 & 23.84 & 3.19 \\
\hline 3 & 0.93 & 0.21 & 81.58 & 18.42 & 4.43 \\
\hline 4 & 0.89 & 0.18 & 83.18 & 16.82 & 4.94 \\
\hline 5 & 0.58 & 0.46 & 55.77 & 44.23 & 1.26 \\
\hline 6 & 0.74 & 0.07 & 91.36 & 8.64 & 10.57 \\
\hline 7 & 1.10 & 0.12 & 90.16 & 9.84 & 9.17 \\
\hline 8 & 0.79 & 0.10 & 88.76 & 11.24 & 7.90 \\
\hline 9 & 0.41 & 0.13 & 75.93 & 24.07 & 3.15 \\
\hline 10 & - & - & 92.00 & 8.00 & 11.50 \\
\hline
\end{tabular}




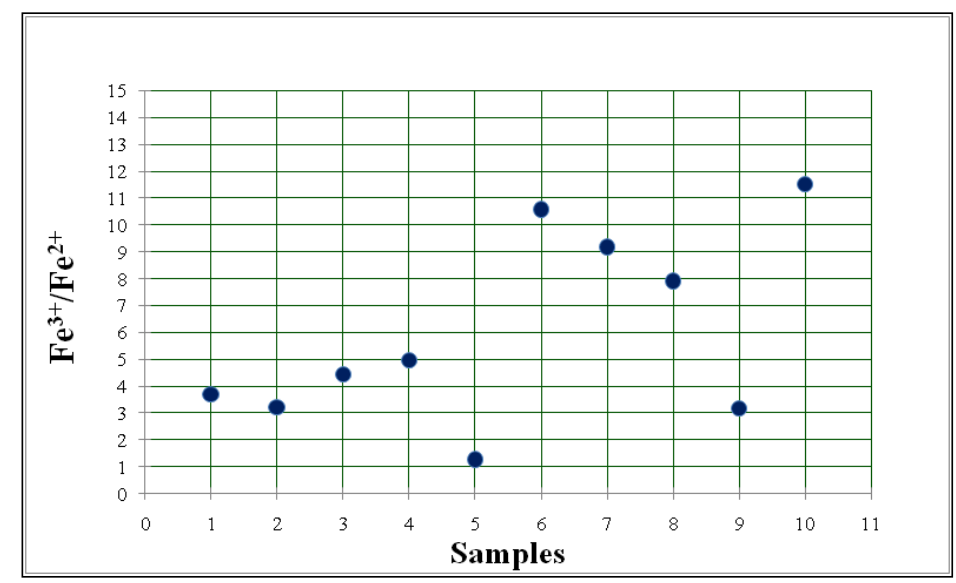

Figure 9 - $\mathrm{Fe}^{3+} / \mathrm{Fe}^{2+}$ ratios in Fe-illlite-glauconite-celadonite group clay minerals on the basis of chemical analyses and Mössbauer spectroscopic data (see Table 1).

\section{References}

Bailey, S., 1980. Summary of recommendations of AIPEA nomenclature committee on clay minerals. Available at: http://www.clays.org/journal/archive/volume\%2028/28-1-73.pdf.

Barth, M., Mason, P., Davies, G., Dijkstra, A. and Drury, M., 2003. Geochemistry or the Othris Ophiolite, Greece: Evidence for Refertilization? J. Petrol., 44, 759-1785.

Barth, M. and Gluhak, M., 2008. Geochemistry and tectonic setting of mafic rocks from the Othris Ophiolite, Greece, Contrib. Mineral. Petrol., 157, 23-40.

Buckley, H.A., Bevan, J.C., Brown, K.M., Johnson, L.R. and Farmer, V.C., 1978. Glauconite and celadonite: two separate mineral species, Min. Mag., 42, 373-82.

Dainyak, L.G. and Drits, V.A., 1987. Interpretation of Mössbauer spectra of notro-nite, celadonite and glauconite, Clays Clay Mineral., 35, 363-372.

Drits, V.A., Dainyak, L.G., Muller, F., Besson, G. and Manceau, A., 1997. Isomorphous cation distribution in celadonites, glauconites and Fe-illites determined by infrared, Mössbauer and EXAFS spectroscopies, Clay Minerals, 32, 153-179.

Drits, V.A., Zviagina, B.B., McCarty, D.K. and Salyn, A.L., 2010. Factors for crystal-chemical variations in the solid solutions from illite to aluminoceladonite and from glauconite to celadonite, Am. Mineral., 85, 348-361.

Dyar, M.D., Agresti, D.G., Schaefer, M.W., Grant, C.A. and Sklute, E.C., 2006. Mössbauer Spectroscopy of Earth and Planetary Materials, Annual Review of Earth and Planetary Sciences, 34, 83-125.

Keith T.E.C. and Staples, L.W., 1985. Zeolites in Eocene Basaltic Pillow Lavas of the Siletz River Volcanics, Central Coast Range, Oregon, Clays Clay Mineral., 33/2, 135-144.

Koutsovitis, P., Magganas, A. and Ntaflos, Th., 2012. Rift and intra-oceanic subduction sig-natures in the Western Tethys during the Triassic: The case of ultramafic lavas as part of an unusual ultramafic-mafic-felsic suite in Othris, Greece, Lithos, 144-145, 177-193.

Martin, R.T., Bailey, S.W., Eberl, D.D., Fanning, D.S., Guggenheim, S., Kodama, H., Pevear, D.R., Srodon, J. and Wicks, F.J., 1991. Report of the clay mineral society nomenclature committee: Revised classification of clay minerals. Available at: http://www.clays.org/journal/archive/volume\%2039/39-3-333.pdf.

Meunier, A., 2005. Clays, Springer, Berlin-Heidelberg-New York.

Odin, G.S., Desrairies, A., Fullagar, P.D., Bellon, H., Decarreau, A., Frohlich, F. and Zelvelder, M., 1988. Nature and geological significance of celadonite, Green Marine Clays-Developments in Sedimentology, 45, 337-398. 
Pe-Piper, G. and Piper, D.J.W., 2002. The Igneous Rocks of Greece, Beiträge zur regionalen Geologie der Erde, Band 30, 537 pp.

Slonimskaya, M.V., Besson, G., Dainyak, L.G., Tchoubar, C. and Drits, V.A., 1986. Interpretation of the IR spectra of celadonites nad glauconites in the region of $\mathrm{OH}$-stretching frequencies, Clay Mineral., 21, 377-388.

Tsikouras, V., Pe-Piper, G., Piper, D.J.W. and Hatzipanagiotou, K., 2008. Triassic rist-related komatiite, picrate and basalt, Pelagonian continental margin, Greece, Lithos, 104, 199-215.

Zhukhlistov, A.P., 2005. Crystal structure of Celadonite from the Electron Diffraction Data, Crystallography Reports, 50/ 6, 902-906. 